\title{
School-leavers between education and the labour market. Facts and figures
}

Citation for published version (APA):

Meng, C. M., \& Sijbers, E. M. (2015). School-leavers between education and the labour market. Facts and figures. ROA. ROA Fact Sheets No. 001E https://doi.org/10.26481/umarof.2015001E

Document status and date:

Published: 01/01/2015

DOI:

10.26481/umarof.2015001E

Document Version:

Publisher's PDF, also known as Version of record

\section{Please check the document version of this publication:}

- A submitted manuscript is the version of the article upon submission and before peer-review. There can be important differences between the submitted version and the official published version of record.

People interested in the research are advised to contact the author for the final version of the publication, or visit the DOI to the publisher's website.

- The final author version and the galley proof are versions of the publication after peer review.

- The final published version features the final layout of the paper including the volume, issue and page numbers.

Link to publication

\footnotetext{
General rights rights.

- You may freely distribute the URL identifying the publication in the public portal. please follow below link for the End User Agreement:

www.umlib.nl/taverne-license

Take down policy

If you believe that this document breaches copyright please contact us at:

repository@maastrichtuniversity.nl

providing details and we will investigate your claim.
}

Copyright and moral rights for the publications made accessible in the public portal are retained by the authors and/or other copyright owners and it is a condition of accessing publications that users recognise and abide by the legal requirements associated with these

- Users may download and print one copy of any publication from the public portal for the purpose of private study or research.

- You may not further distribute the material or use it for any profit-making activity or commercial gain

If the publication is distributed under the terms of Article $25 \mathrm{fa}$ of the Dutch Copyright Act, indicated by the "Taverne" license above, 
Dus Maastricht University in Learning!

Research Centre for Education and the Labour Market | ROA

\section{School-leavers between education and the labour market 2014 \\ Facts and figures}

\section{ROA Fact Sheet}

ROA-F-2015/1E

Researchcentrum voor Onderwijs en Arbeidsmarkt | ROA Research Centre For Education and the Labour Market / ROA 


\section{Introduction}

Every year, ROA carries out a survey among school-leavers on the transition from school to the labour market or to subsequent education programmes. This fact sheet presents the results of the survey conducted by ROA among school leavers who graduated in the school year 2012-20I3. The survey was held in the final months of 2014, which is approximately eighteen months after graduation. For the full results, please refer to the ROA report "Schoolverlaters tussen onderwijs en arbeidsmarkt 2014" (in Dutch). A total of 89,037 school-leavers and graduates were approached. The total response rate was $30 \%$.

The results cover almost the entire educational spectrum in the Netherlands: Preparatory Secondary Vocational Education (PSVE), Secondary Vocational Education - School-based Learning Route (SVE-VT), Secondary Vocational Education - Work-based Route (SVE-DR), Senior General Secondary Education (SGSE), Pre-University Education (PUE) and Higher Vocational Education (HVE). Within SVE, a double distinction is made. First of all, there is a distinction between two different learning routes (VT and DR). Secondly, within each learning route 4 levels are distinguished. The results in the fact sheet are presented per education sector, but the annex also provides an overview of the figures for each education level differentiated by field of education. For reasons of comparability, the results for HVE only relate to graduates from full-time programmes.

The results from the survey among school-leavers and graduates should be viewed within the broader context of the current economic climate. Not only have the past few years been characterised by a worldwide financial crisis, but this was also followed by a debt crisis within the Euro zone. The Netherlands has experienced relatively lean years since the financial crisis started in 2009, but there are signs of recovery. The influence of the economic situation applies not only to the indicators that are directly related to labour market entry (e.g. unemployment or tenure), but may also affect the way in which young people assess the education programmes from which they graduated. Readers should bear this in mind.

\section{Preparation for the labour market}

Intermediate and higher vocational education programmes aim to prepare young people for a position in the labour market. Table I shows the percentage of qualified schoolleavers who feel that the programme that they completed provided a good or very good basis for labour market entry. In addition to preparing for labour market entry, education programmes also aim to provide a basis for further development of knowledge and skills in the subsequent professional and educational career. For this reason, Table
I also shows the percentage of certified school-leavers who feel that the programme that they completed provided a good or very good basis for further development of knowledge and skills. Of all SVE graduates, a total of $57 \%$ feel that their education programme provides a good basis for such further development, compared to $43 \%$ who think that the programme is a good basis for labour market entry. A notable fact within SVE is that the DR programmes score considerably better as a basis for labour market entry (52\%) than the VT programmes (37\%). This can be explained by the fact that SVE-DR students are assigned a considerably higher number of working hours in companies during their programme than their SVE-VT peers. However, SVE-DR programmes also outperform VT programmes as a basis for further development of skills (6I\% versus $55 \%$ ). Within SVE-VT, programmes at Level 2 generally score best as both a basis for labour market entry and for further development of knowledge and skills (42\% and 60\%, respectively). Within SVE-VT, the programmes at Level 3 score best for both aspects (6I\% and $66 \%)$.

A little less than half of the HVE graduates feel that the programme completed constitutes a good or very good basis for labour market entry (47\%). In addition, $63 \%$ consider the programme a good or very good basis for further development of knowledge and skills.

\section{Table 1}

Education programme as preparation for the labour market and further development of knowledge and skills (\%)

\begin{tabular}{|l|c|c|}
\hline & Labour market entry & $\begin{array}{c}\text { Further development of } \\
\text { knowledge and skills } \\
\text { Good/very good basis (\%) }\end{array}$ \\
\hline SVE-VT 1 & 31 & 54 \\
\hline SVE-VT 2 & 42 & 60 \\
\hline SVE-VT 3 & 38 & 54 \\
\hline SVE-VT 4 & 36 & 54 \\
\hline SVE-DR 1 & 35 & 47 \\
\hline SVE-DR 2 & 49 & 58 \\
\hline SVE-DR 3 & 61 & 66 \\
\hline SVE-DR 4 & 49 & 61 \\
\hline HVE & 47 & 63 \\
\hline
\end{tabular}

\section{Success in the labour market}

The returns of an education programme in economic terms depends on a number of factors at the time of labour market entry. The labour market entry of graduates from SVE and HVE has therefore been analysed on the basis of various indicators.

Firstly, we look at the level of unemployment among school-leavers who enter the labour market (Figure I). Total unemployment among school-leavers at the time of the survey was $8.6 \%$, which constitutes a I.I percentage point increase compared with the survey conducted in the Autumn

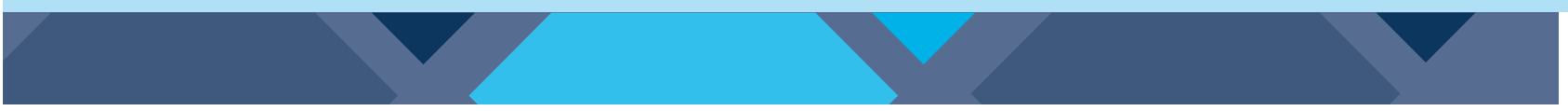


of 2013. ${ }^{.}$The unemployment rate of VT graduates differs considerably from the unemployment rate of DR graduates. Of the school-leavers from SVE-VT Level 2, no less than $2 \mathrm{I} \%$ are unemployed, while among the school-leavers from SVE-DR Level 2, the figure is 6\%. Unemployment of SVE school-leavers also differs considerably between the lower and higher levels. Whereas the unemployment rate is $9 \%$ for VT Level 4, for VT Level I it is $28 \%$. Within DR, graduates from Level I also have a higher unemployment rate than graduates from DR Level 4 , but the difference between these levels - II\% versus $4 \%$ - is much smaller than in VT. Compared with 2013, unemployment of graduates from full-time HVE programmes dropped by I percentage point, to $7 \%$ in 2014 .

\section{Figure 1}

Unemployment at the time of the survey (\%)

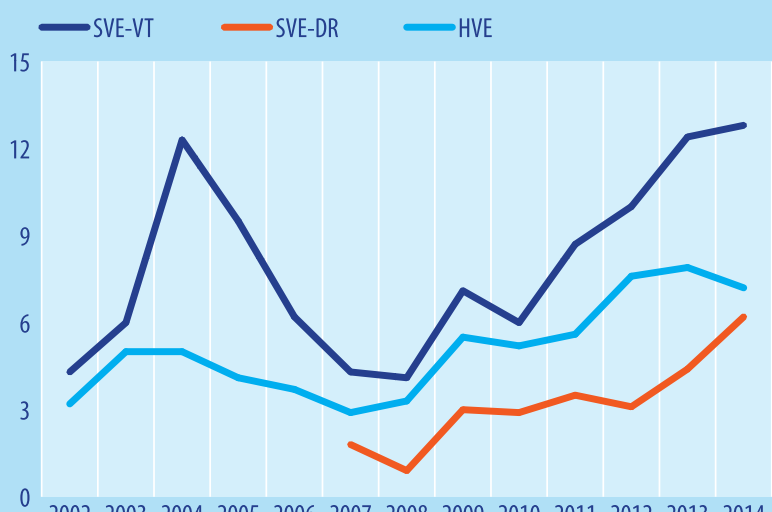

$0 \quad 2002200320042005200620072008200920102011201220132014$

The unemployment rate at the time of the survey is not the only indicator of the smoothness of labour market entry. For this reason, Figure 2 shows results relating to the duration of the search for the first job. Differences can be seen between graduates from the School-based Learning Route (SVE-VT) and the Work-based Learning Route (SVE-DR). On average across all four levels, $21 \%$ of the SVE-VT graduates experienced some entry unemployment, compared to I2\% of the SVE-DR graduates. For schoolleavers with an SVE-VT diploma, the entry unemployment rate varies greatly for different levels of the education programme. Graduates from Level I suffer most from entry unemployment $(28 \%$, of whom I6 percentage points were unemployed for more than 3 months), followed by Level 2 ( $25 \%$, I7 percentage points longer than 3 months), Level
3 (20\%, I7 percentage points longer than 3 months), and Level 4 ( $18 \%$, I2 percentage points longer than 3 months). For SVE-DR, graduates at Level 2 have the greatest trouble finding a job ( $15 \%$, of whom 8 percentage points more than 3 months), while Level 4 graduates have the least problems ( $8 \%, 3$ percentage points longer than 3 months). The results also show that HVE graduates appear to have more trouble finding a job than SVE graduates. No less than $35 \%$ of HVE graduates experience entry unemployment, compared to $17 \%$ of the SVE graduates.

Figure 2

Entry unemployment (\%)
OMONTHS

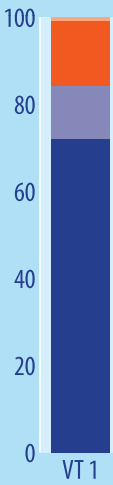

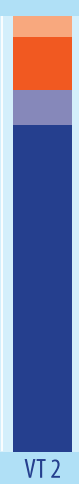

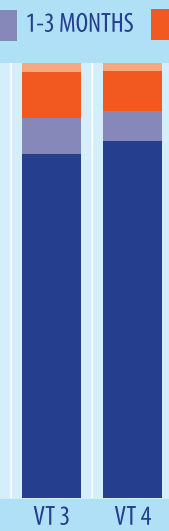

4-12 MONTHS

$>12$ MONTHS

In addition to unemployment rates, there are some other important indicators that illustrate the quality of the transition between education and the labour market. Figure 3 shows how well the school-leavers' jobs match the programmes that they completed in terms of level and field of education. Of all working school-leavers, on average $67 \%$ have a job that at least matches their education level. This is a decrease compared to last year, when $71 \%$ had a job requiring at least their own education level. Graduates from SVE-DR Levels 3 and 4 are most likely to find a job that at least matches the level of the programme they have completed: $84 \%$ of these graduates reported this. $68 \%$ of all SVE graduates find a job that requires at least their own level of completed education, with DR graduates doing slightly better (71\%) than VT graduates (65\%). At HVE level, on average $74 \%$ have a job that at least matches their own education level.

I Starting this year, the School-leaver Information System project, which serves as the basis for this fact sheet, defines the working population in accordance with the definition used by the International Labour Organisation (ILO). This internationally accepted standard states that persons older than Is years who work more than I hour per week are part of the working population. The definition used previously applied a minimum limit of $\mathrm{I} 2$ hours. To allow conclusions to be drawn about developments across multiple years, the figures from preceding years were recalculated in accordance with the ILO standard. As a result, figures in this edition that relate to surveys from previous years (2013 and before) do not match those in publications from previous years. 
Figure 3

Match between job and education programme completed

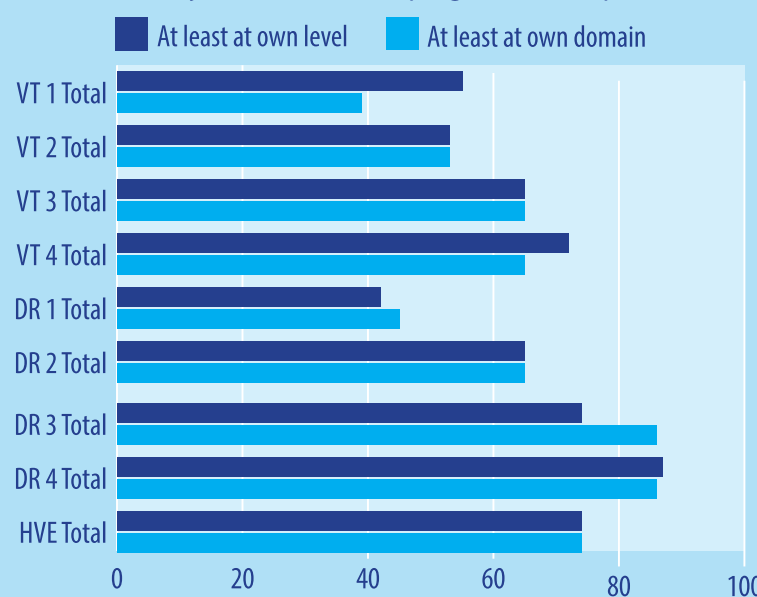

In addition to the level of the job, the type of job is also an important factor determining the quality of employment. Figure 3 shows that school-leavers with a diploma from the lowest level within SVE are the least likely to work within their own occupational domain. Graduates from SVE-DR Levels 3 and 4 are most likely to work within their own occupational domain. Of all SVE-VT Level 3 and 4 graduates, approximately $70 \%$ work within their own occupational domain, whereas for DR graduates at these levels, this applies to $83 \%$ at Level 3 and as much as $87 \%$ at Level 4. HVE graduates are in between these: $74 \%$ works in their own or a related domain.

Respondents were also asked to give an assessment of the overall match between the programme that they had completed and their current job. Figure 4 shows the proportion of working school-leavers who considered this match sufficient or good. DR graduates at all levels are most often satisfied with the match. A possible explanation for this is the close relationship between education and the labour market in DR. $7 \mathrm{I} \%$ of the working graduates at HVE level rated the match between the education programme and work as sufficient or good. Although workers at VT Level I are the least satisfied with their match, $60 \%$ of the workers in this group still feel that the match between the education programme and their current job is sufficient or good.
Figure 4

Match between programme completed and current job (\%)

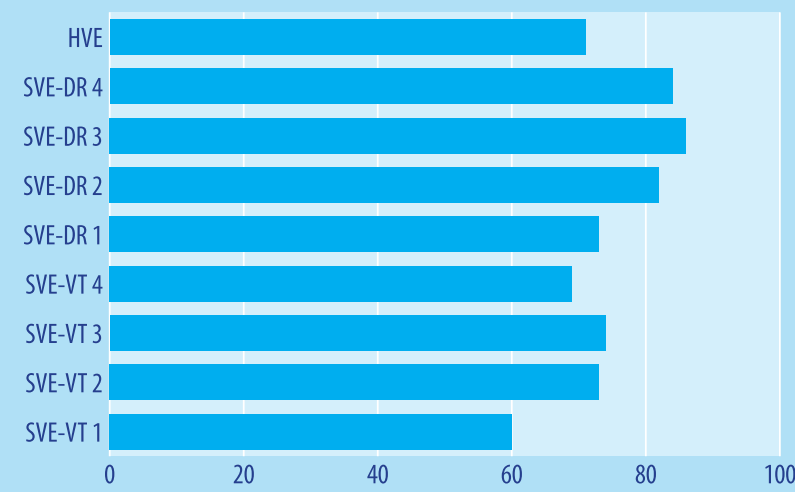

Another indicator of the quality of work and the transition from education to the labour market is the wage received by working school-leavers. Table 2 shows the average gross hourly wage for each education level. Hourly wage allows a better comparison than monthly earnings, as differences in monthly earnings can also be affected by the number of hours worked. As expected, the average gross hourly wage increases with education level. The only exception is that graduates from SVE-DR Level 4 earn a higher hourly wage $(€ \mathrm{I} 3.80)$ than HVE graduates $(€ \mathrm{I} 3.25)$. Among VT graduates, the average gross hourly wage varies from $€ 5.85$ (Level I) to $€ 9.45$ (Level 4 ), while at DR level, average earnings vary between $€ 9.65$ (Level I) and $€ \mathrm{I} 3.60$ (Level 4 ).

Table 2

Average gross hourly wages $(€)$

\begin{tabular}{l|r} 
& uurloon \\
\hline SVE-VT 1 & 5,85 \\
\hline SVE-VT 2 & 7,45 \\
\hline SVE-VT 3 & 8,85 \\
\hline SVE-VT 4 & 9,45 \\
\hline SVE-DR 1 & 9,65 \\
\hline SVE-DR 2 & 9,90 \\
\hline SVE-DR 3 & 12,05 \\
SVE-DR 4 & 13,80 \\
\hline HVE & 13,25 \\
Hourly wages rounded to nearest 5 eurocent &
\end{tabular}

\section{Level of job satisfaction}

Although unemployment rates, the education-job match and hourly wage are important indicators of the labour market returns to an education programme, the level of satisfaction of school-leavers with their jobs is perhaps even more important. Table 3 shows for each education level how satisfied graduates are with their current jobs and with the career perspectives offered by those jobs.

On average $65 \%$ of all school-leavers are satisfied with their current jobs. Graduates at DR Level 3 are most satisfied $(72 \%)$.

Graduates are more critical with respect to their career perspectives. On average, $48 \%$ feel that the career perspectives offered by their jobs are good. Again, working gradu- 
ates from DR Level 3 score highest, with $53 \%$ of them reporting that their jobs offer good career perspectives. The school-leavers from the lowest level are the least satisfied. Both at VT Level I and at DR Level I, only one third of the respondents $(32 \%)$ report that their jobs offer good career perspectives.

Table 3

Level of satisfaction with current job and career perspectives (\%)

\begin{tabular}{|l|r|r|r|r|r|r|r|r|r|} 
& VT 1 & VT 2 & VT 3 & VT 4 & DR 1 & DR 2 & DR 3 & DR 4 & HVE \\
\hline $\begin{array}{l}\text { Satisfied with job } \\
\text { Good career }\end{array}$ & 53 & 68 & 59 & 63 & 63 & 65 & 72 & 65 & 63 \\
\hline \begin{tabular}{l} 
perspectives \\
\hline
\end{tabular} & 32 & 47 & 44 & 44 & 32 & 50 & 53 & 45 & 51 \\
\hline
\end{tabular}

\section{Transition to further education}

After graduation, young people may choose to continue their educational career instead of entering the labour market. Figure 5 gives an overview of the educational followup routes for the graduates from this survey. The figure lists for each type of education the percentage of graduates who entered a particular educational follow-up route since their graduation, as well as the percentage that did not opt for follow-up route. For greater clarity, this figure combines VT and DR levels, and only follow-up routes with a share of at least 5\% have been included. From General Secondary Education (GSE) the vast majority of graduates proceed to further education. $79 \%$ of the entire group of SGSE respondents continued on to a HVE programme. I7\% of PUE graduates went on to a HE programme, the majority of whom (76\%) opted for University Education (UE). $2 \%$ of PSVE graduates decided not to proceed on to a subsequent education programme. The percentage of PSVE schoolleavers moving on to SGSE is almost $8 \%$. I3\% of SGSE graduates refrain from proceeding to a educational followup route, while this applies to $6 \%$ of PUE graduates. These are often young people taking a year off.

Figure 5

Educational follow-up routes after graduation

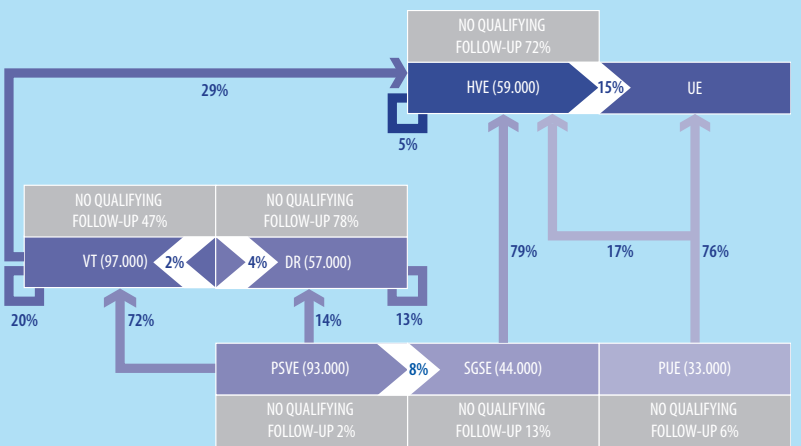

School-leavers who had moved on to further education were asked what they thought of the match between the programme that they had completed and the subsequent programme. Figure 6 shows the proportion of these school- leavers who considered this match sufficient or good. The vast majority of those who moved on to further education thought that this was the case.

Strikingly, among SVE-VT school-leavers, the satisfaction with the quality of the match clearly decreases with the level of the programme. Whereas $83 \%$ of the Level I SVE-VT graduates are satisfied with the match, this 'only' applies to $55 \%$ of SVE-VT graduates at the highest level. This implies that over $45 \%$ of these graduates consider the match moderate to poor. We need to keep in mind hereby that most lower level SVE-VT school-leavers move on to subsequent programmes within SVE, whereas for Level 4 SVE school-leavers, continuing their education generally means switching to HVE.

Apart from the match, another measure for the quality of the transition to further education is the drop-out rate. Figure 7 shows the percentage of young people who prematurely leave the subsequent programme without starting a new one (the net drop-out rate), as well as the percentage who switched programmes. In all, $9 \%$ of respondents indicated that they had left the subsequent programme that they had initially chosen. Of this group, 6 percentage points indicated that they had switched programmes, while 3 percentage points had stopped without embarking on another programme. Graduates from SVE-VT Level 4 show the highest dropout level: in all, $17 \%$ replied that they had left the subsequent programme.

Figure 6

Match between programme completed and subsequent programme $(\%)$

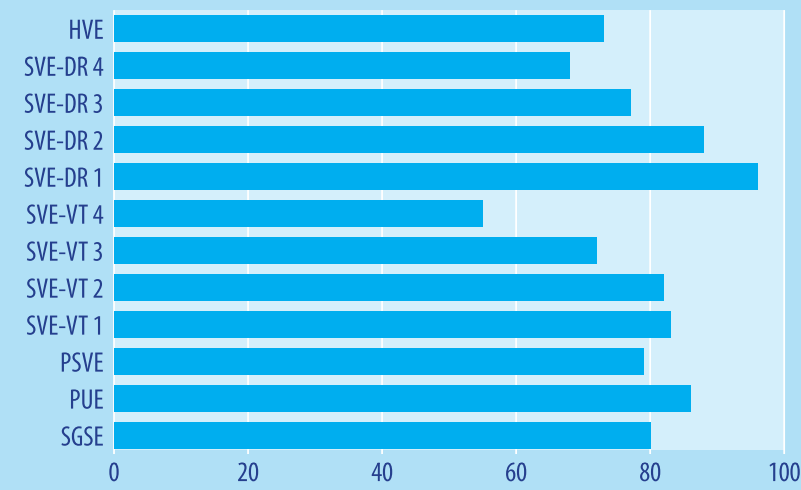

It is immediately clear that there is a large difference between SVE-DR and SVE-VT. In all, $13 \%$ of SVE-VT graduates prematurely left their subsequent programme, compared to $4 \%$ for SVE-DR. Moreover, $6 \%$ of SVE-VT graduates switched programmes, which was hardly ever the case for SVE-DR. 
Figure 7

Net drop-out rate and programme switchers (\%)

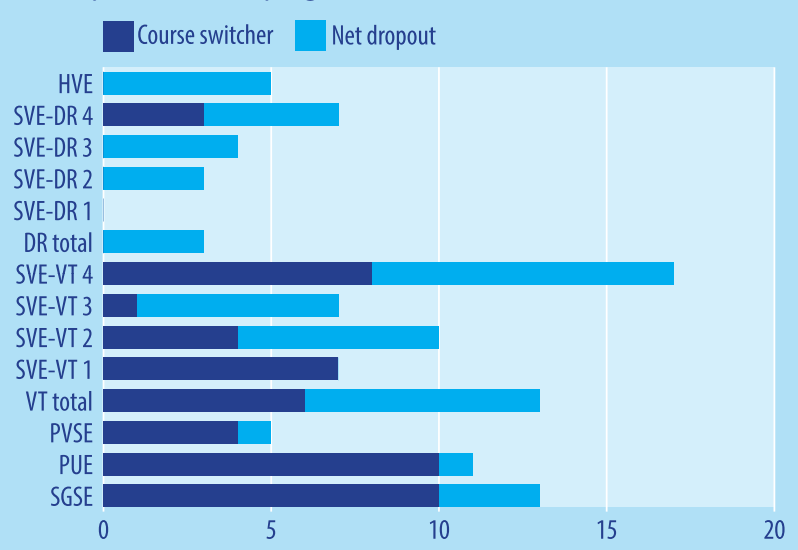

\section{Satisfaction with education} programme

Various indicators were used to measure the level of satisfaction of school-leavers with the completed education programme. The survey looked both at education-specific issues (such as the content of the programmes, teaching methods, etc.), as well as more material and practical aspects (such as facilities).

For most of the aspects, the conclusion can be drawn that SGSE/PUE graduates are more satisfied than their PSVE and SVE counterparts. The atmosphere at school is particularly appreciated by these graduates: almost $80 \%$ of all graduates from SGSE/PUE were satisfied or very satisfied with this aspect. For most of aspects, SVE graduates showed the lowest satisfaction scores: material facilities (42\%), accommodation ( $52 \%)$, quality of exams $(47 \%)$, the mode of examination $(47 \%)$, the subject content $(40 \%)$, teaching methods $(48 \%)$, provision of study information $(35 \%)$ and the atmosphere at school (57\%). An exception to the rule is seen with regard to the amount of practical training, for which SVE shows the highest score (5I\%). It needs to be kept in mind however that SVE offers vocational training, and that half of the students are thus not satisfied with the amount of practical training. SVE-DR students are marginally more satisfied than SVE-VT students, with $49 \%$ of VT graduates being satisfied with the amount of practical training in their programme, compared to $53 \%$ of DR graduates.
As a concluding assessment, graduates were asked whether - looking back - they would choose the same education programme again (see Table 4). Approximately 80\% of all graduates would choose the same programme again. This percentage shows that a large majority of respondents are still satisfied with the choice they made with respect to their education programme. The highest score is obtained in GSE, where no less than $97 \%$ would choose the same programme again. The number of graduates who would choose a different programme is highest among SVE-VT graduates. 23\% (Level 4 ) to $32 \%$ (Level I) of SVE-VT graduates would choose a different programme if they could make the choice again. Among SVE-DR graduates, I6\% (Level 4) to $24 \%$ (Level I) would change their choice if they could. $77 \%$ of HVE graduates would choose the same programme again if they had the choice.

Table 4

Level of satisfaction looking back (\%)

\begin{tabular}{|c|c|c|}
\hline & \multicolumn{2}{|c|}{ Choice of programme } \\
\hline & Same programme & Different programme \\
\hline SGSE/PUE & 97 & 3 \\
\hline PSVE & 88 & 12 \\
\hline SVE-VT 1 & 68 & 32 \\
\hline SVE-VT 2 & 73 & 27 \\
\hline SVE-VT 3 & 74 & 26 \\
\hline SVE-VT 4 & 77 & 23 \\
\hline SVE-DR 1 & 76 & 24 \\
\hline SVE-DR 2 & 84 & 16 \\
\hline SVE-DR 3 & 82 & 18 \\
\hline SVE-DR 4 & 85 & 15 \\
\hline
\end{tabular}

HVE

77

23 


\section{General}

\begin{tabular}{|c|c|c|c|}
\hline & $\begin{array}{l}\text { Course provides a good basis for } \\
\text { labour market entry (\%) }\end{array}$ & $\begin{array}{l}\text { Course provides a good basis for further } \\
\text { development of knowledge and skills (\%) }\end{array}$ & Looking back, choose course again (\%) \\
\hline PSVE & 27 & 57 & 88 \\
\hline PSVE theoretical programme & 25 & 56 & 88 \\
\hline PSVE Agriculture & 24 & 55 & 89 \\
\hline PSVE Technology & 39 & 63 & 87 \\
\hline PSVE Economics & 32 & 54 & 87 \\
\hline PSVE Health Care & 23 & 60 & 87 \\
\hline PSVE intersectoral & 24 & 55 & 86 \\
\hline SVE & 43 & 57 & 78 \\
\hline VT & 37 & 55 & 75 \\
\hline VT 1 & 31 & 54 & 68 \\
\hline VT 2 & 42 & 60 & 73 \\
\hline VT 2 Agriculture & 43 & 60 & 68 \\
\hline VT 2 Technology & 38 & 54 & 72 \\
\hline VT 2 Economics & 47 & 63 & 71 \\
\hline VT 2 Health Care & 38 & 61 & 75 \\
\hline VT 3 & 38 & 54 & 74 \\
\hline VT 3 Agriculture & 34 & 51 & 65 \\
\hline VT 3 Technology & 47 & 48 & 77 \\
\hline VT 3 Economics & 36 & 50 & 73 \\
\hline VT 3 Health Care & 49 & 62 & 77 \\
\hline VT 3 Behaviour \& Society & 28 & 56 & 72 \\
\hline VT 4 & 36 & 54 & 77 \\
\hline VT 4 Agriculture & 38 & 51 & 74 \\
\hline VT 4 Technology & 45 & 58 & 76 \\
\hline VT 4 Economics & 32 & 52 & 75 \\
\hline VT 4 Health Care & 44 & 61 & 83 \\
\hline VT 4 Behaviour \& Society & 27 & 51 & 75 \\
\hline DR & 52 & 61 & 83 \\
\hline DR 1 & 35 & 47 & 76 \\
\hline $\mathrm{DR} 2$ & 49 & 58 & 84 \\
\hline DR 2 Agriculture & 47 & 58 & 89 \\
\hline DR 2 Technology & 51 & 56 & 87 \\
\hline DR 2 Economics & 47 & 62 & 77 \\
\hline DR 2 Health Care & 49 & 63 & 81 \\
\hline DR 3 & 61 & 66 & 82 \\
\hline DR 3 Agriculture & 59 & 66 & 83 \\
\hline DR 3 Technology & 67 & 68 & 81 \\
\hline DR 3 Economics & 43 & 50 & 74 \\
\hline DR 3 Health Care & 74 & 77 & 86 \\
\hline DR 3 Behaviour \& Society & 51 & 78 & 92 \\
\hline
\end{tabular}




\section{General}

Course provides a good basis for labour market entry (\%)
Course provides a good basis for further development of knowledge and skills (\%)
Looking back, choose course again (\%)

DR 4 Agriculture

DR 4 Technology

DR 4 Economics

DR 4 Health Care

DR 4 Behaviour \& Society

HVE

HVE Agriculture

HVE Technology

HVE Economics

HVE Health Care

HVE Behaviour \& Society

HVE Education

HVE Language \& Culture

$\begin{array}{ll}49 & 6 \\ 48 & 6 \\ 38 & 62 \\ 37 & 46 \\ 65 & 70 \\ 47 & 59\end{array}$

61
64
62
46
70
59

$\begin{array}{lll}47 & 63 & 77 \\ 55 & 67 & 75 \\ 59 & 68 & 84 \\ 46 & 61 & 70 \\ 50 & 68 & 84 \\ 35 & 60 & 72 \\ 50 & 58 & 86 \\ 29 & 70 & 82 \\ 39 & 58 & 84\end{array}$

Total

Source: ROA (SIS)
85

85

$61 \quad 85$

85

$62 \quad 84$

$46 \quad 81$

89

75

89

81

75




\section{Subsequent education}

\begin{tabular}{|c|c|c|c|}
\hline & $\begin{array}{c}\text { match } \\
\text { reasonable/good (\%) }\end{array}$ & $\begin{array}{l}\text { net dropout } \\
\text { in subsequent } \\
\text { course (\%) }\end{array}$ & $\begin{array}{c}\text { Course switcher } \\
\text { in subsequent education (\%) }\end{array}$ \\
\hline SGSE/PUE & 83 & 2 & 10 \\
\hline SGSE & 80 & 3 & 10 \\
\hline PUE & 86 & 1 & 10 \\
\hline PSVE & 79 & 1 & 4 \\
\hline PSVE theoretical programme & 79 & 1 & 5 \\
\hline PSVE Agriculture & 75 & 1 & 5 \\
\hline PSVE Technology & 84 & 2 & 1 \\
\hline PSVE Economics & 84 & 0 & 5 \\
\hline PSVE Health Care & 75 & 1 & 3 \\
\hline PSVE intersectoral & 79 & 1 & 8 \\
\hline SVE & 70 & 6 & 5 \\
\hline VT & 66 & 7 & 6 \\
\hline VT1 & 83 & 1 & 7 \\
\hline VT 2 & 82 & 6 & 4 \\
\hline VT 2 Agriculture & 82 & 4 & 5 \\
\hline VT 2 Technology & 85 & 4 & 6 \\
\hline VT 2 Economics & 79 & 4 & 5 \\
\hline VT 2 Health Care & 85 & 8 & 3 \\
\hline VT 3 & 72 & 6 & 1 \\
\hline VT 3 Agriculture & 76 & 10 & 0 \\
\hline VT 3 Technology & 87 & 2 & 0 \\
\hline VT 3 Economics & 68 & 6 & 1 \\
\hline VT 3 Health Care & 72 & 4 & 2 \\
\hline VT 3 Behaviour \& Society & 75 & 6 & 1 \\
\hline VT 4 & 55 & 9 & 8 \\
\hline VT 4 Agriculture & 53 & 5 & 4 \\
\hline VT 4 Technology & 50 & 10 & 6 \\
\hline VT 4 Economics & 58 & 8 & 9 \\
\hline VT 4 Health Care & 61 & 7 & 8 \\
\hline VT 4 Behaviour \& Society & 52 & 9 & 10 \\
\hline DR & 83 & 4 & 0 \\
\hline DR 1 & 96 & 0 & 0 \\
\hline DR2 & 88 & 3 & 0 \\
\hline DR 3 & 77 & 4 & 0 \\
\hline DR 4 & 68 & 4 & 3 \\
\hline
\end{tabular}




\section{Subsequent education}

match

reasonable/good (\%) net dropout

in subsequent course (\%)
Course switcher

in subsequent education (\%)

$\begin{array}{llll}\text { HVE } & 73 & 5 & 0 \\ \text { HVE Agriculture } & 73 & 3 & 0 \\ \text { HVE Technology } & 67 & 8 & 1 \\ \text { HVE Economics } & 72 & 4 & 0 \\ \text { HVE Health Care } & 79 & 3 & 0 \\ \text { HVE Behaviour \& Society } & 73 & 6 & 0 \\ \text { HVE Education } & 83 & 4 & 0 \\ \text { HVE Language \& Culture } & - & 6 & 6 \\ & & & 3\end{array}$

Source: ROA (SIS) 


\section{Labour market}

\begin{tabular}{|c|c|c|c|c|c|c|}
\hline & $\begin{array}{l}\text { At least at own } \\
\text { level (\%) }\end{array}$ & $\begin{array}{l}\text { Own/related } \\
\text { domain (\%) }\end{array}$ & $\begin{array}{c}\text { Match } \\
\text { sufficient } / \operatorname{good}(\%)\end{array}$ & $\begin{array}{l}\text { Unemployed } \\
(\%)\end{array}$ & $\begin{array}{l}\text { Entry unemployment } \\
>3 \text { months (\%) }\end{array}$ & $\begin{array}{c}\text { Gross hourly wages } \\
\text { (euro) }\end{array}$ \\
\hline SVE & 68 & 69 & 77 & 10 & 10 & 10,16 \\
\hline VT & 65 & 61 & 71 & 13 & 13 & 8,82 \\
\hline VT 1 & 56 & 40 & 60 & 28 & 16 & 5,83 \\
\hline VT 2 & 54 & 53 & 73 & 21 & 17 & 7,46 \\
\hline VT 2 Agriculture & 77 & 65 & 73 & 21 & 15 & 6,66 \\
\hline VT 2 Technology & 61 & 47 & 70 & 26 & 14 & 7,41 \\
\hline VT 2 Economics & 59 & 46 & 67 & 18 & 19 & 7,31 \\
\hline VT 2 Health Care & 61 & 64 & 79 & 20 & 16 & 7,78 \\
\hline VT 3 & 65 & 64 & 74 & 11 & 12 & 8,84 \\
\hline VT 3 Agriculture & 55 & 51 & 62 & 16 & 14 & 7,38 \\
\hline VT 3 Technology & 63 & 64 & 69 & 13 & 20 & 10,32 \\
\hline VT 3 Economics & 58 & 50 & 72 & 14 & 11 & 8,00 \\
\hline VT 3 Health Care & 72 & 81 & 85 & 5 & 11 & 9,78 \\
\hline VT 3 Behaviour \& Society & 71 & 73 & 70 & 8 & 14 & 8,88 \\
\hline VT 4 & 72 & 64 & 69 & 9 & 11 & 9,47 \\
\hline VT 4 Agriculture & 69 & 63 & 59 & 8 & 11 & 8,62 \\
\hline VT 4 Technology & 72 & 69 & 72 & 6 & 11 & 10,06 \\
\hline VT 4 Economics & 65 & 52 & 65 & 15 & 13 & 8,52 \\
\hline VT 4 Health Care & 84 & 81 & 80 & 6 & 9 & 10,58 \\
\hline VT 4 Behaviour \& Society & 66 & 55 & 59 & 9 & 11 & 9,00 \\
\hline DR & 71 & 75 & 83 & 6 & 6 & 11,43 \\
\hline DR 1 & 46 & 44 & 73 & 11 & 7 & 9,63 \\
\hline DR2 & 65 & 66 & 82 & 6 & 8 & 9,92 \\
\hline DR 2 Agriculture & 60 & 57 & 84 & 1 & 5 & 9,19 \\
\hline DR 2 Technology & 66 & 65 & 82 & 2 & 7 & 10,22 \\
\hline DR 2 Economics & 60 & 67 & 75 & 19 & 15 & 8,37 \\
\hline DR 2 Behaviour \& Society & 71 & 72 & 87 & 6 & 6 & 11,25 \\
\hline DR3 & 74 & 86 & 86 & 6 & 6 & 12,04 \\
\hline DR 3 Agriculture & 72 & 83 & 86 & 3 & 2 & 11,33 \\
\hline DR 3 Technology & 74 & 85 & 84 & 4 & 6 & 12,33 \\
\hline DR 3 Economics & 54 & 75 & 78 & 12 & 9 & 10,19 \\
\hline DR 3 Health Care & 83 & 94 & 92 & 3 & 0 & 12,77 \\
\hline DR 3 Behaviour \& Society & 88 & 92 & 91 & 7 & 6 & 14,22 \\
\hline DR 4 & 87 & 86 & 84 & 4 & 3 & 13,79 \\
\hline DR 4 Agriculture & 78 & 73 & 81 & 6 & 6 & 13,04 \\
\hline DR 4 Technology & 79 & 86 & 81 & 2 & 4 & 14,46 \\
\hline DR 4 Economics & 78 & 72 & 87 & 5 & 4 & 12,20 \\
\hline DR 4 Health Care & 87 & 98 & 86 & 2 & 1 & 14,32 \\
\hline DR 4 Behaviour \& Society & - & - & - & 16 & 6 & - \\
\hline
\end{tabular}




\section{Labour market}

$\begin{array}{cccccc}\text { At least at own } & \text { Own/related } & \text { Match } & \text { Unemployed } & \text { Entry unemployment } & \text { Gross hourly wages } \\ \text { level (\%) } & \text { domain (\%) } & \text { sufficient/good (\%) } & (\%) & >3 \text { months (\%) } & \text { (euro) }\end{array}$

HVE

HVE Agriculture

HVE Technology

$74 \quad 7$

HVE Economics

73

HVE Health Care

84

75

HVE Behaviour \& Society

HVE Education

HVE Language \& Culture

79

49

87

87
64

74
70
82
64
89
71
88
64

71
68
77
66
82
64
81
68

$7 \quad 20$

$20 \quad 13,26$

Total

70

75

$\begin{array}{lll}8 & 19 & 13,09 \\ 6 & 17 & 14,11 \\ 8 & 20 & 12,95 \\ 4 & 19 & 14,81 \\ 9 & 27 & 12,77 \\ 6 & 19 & 14,12 \\ 7 & 18 & 10,10\end{array}$

Source: ROA (SIS)

70

13

11,06 


\section{Unemployment trend}

\begin{tabular}{|c|c|c|c|c|c|c|c|c|c|c|c|c|}
\hline & 2003 & 2004 & 2005 & 2006 & 2007 & 2008 & 2009 & 2010 & 2011 & 2012 & 2013 & 2014 \\
\hline SVE-VT 1/2 & 14 & 23 & 19 & 11 & 8 & 8 & 12 & 12 & 16 & 16 & 21 & 22 \\
\hline SVE-VT $3 / 4$ & 3 & 8 & 6 & 5 & 2 & 3 & 5 & 4 & 6 & 8 & 10 & 10 \\
\hline SVE-DR $1 / 2$ & 4 & 5 & 6 & 3 & 3 & 1 & 4 & 4 & 5 & 4 & 6 & 7 \\
\hline SVE-DR $3 / 4$ & 2 & 4 & 2 & 2 & 1 & 1 & 2 & 2 & 2 & 2 & 3 & 5 \\
\hline HVE & 5 & 5 & 4 & 4 & 3 & 3 & 5 & 5 & 6 & 8 & 8 & 7 \\
\hline
\end{tabular}

$-:$ not available

Note: The year is the year of the survey In 2012, respondents came from the 2010-2011 survey,

Comment: In the 2000-2002 surveys, this concerns Lower Secondary General Education (LGSE)/Initial Professional Education (IPE) schoolleavers. From the 2003 survey onwards these are PSVE school-leavers. 


\section{Imprint}

(C) Research Centre for Education and the Labour Market (ROA). Nothing in this publication may be duplicated in any way without prior written permission from ROA's director.

Research Centre for Education and the Labour Market

Maastricht University

School of Business and Economics

secretary-roa-sbe@maastrichtuniversity.nl

www.roa.nl

Layout

ROA Secretariat, Maastricht

October 2015 
Researchcentrum voor Onderwijs en Arbeidsmarkt

Postbus 616

6200 MD Maastricht

$\mathrm{T}+31433883647$

F +31 433884914

secretary-roa-sbe@maastrichtuniversity.nl

www.roa.nl

Maastricht University

School of Business and Economics 